\title{
A Rapid Method for Screening Macadamia Seedlings for Resistance to Kretzschmaria clavus*
}

\author{
Wen-hsiung Ko** and Richard K. Kunimoto** \\ Key words : Macadamia integrifolia, Macadamia ternifolia, Kretzschmaria clavus, root rot, \\ resistance.
}

Nuts of macadamia (Macadamia integrifolia Maiden \& Betche) are one of the famous delicacies of Hawaii. Macadamia trees have been planted mostly on the island of Hawaii, and the industry has expanded rapidly in recent years. Root rot caused by Kretzschmaria clavus (Fr.) Sace. of the Xylariaceas is the most serious disease problem of macadamia in Hawaii ${ }^{1)}$. The disease causes an unthrifty appearance, followed by defoliation and death of trees that are older than 6 years of age. Kretzschmaria clavus forms black lines in infected roots and trunks, and produces kretzschmarioid and hypoxyloid stromata on the surface of infected tissues ${ }^{2)}$. Attempts to control the disease by injecting infected trees with fungicides have not been successful because extensive root damage usually precedes the appearance of external symptoms on the trees. Use of resistant root stocks has been considered a promising approach to solve this disease problem. However, advancement of the disease is extremely slow. Six months after inoculation, $K$. clavus colonizes only a few $\mathrm{mm}$ of the inoculated root tissues. It is, therefore, very difficult to compare susceptibility among macadamia trees. We report here a rapid method for screening macadamia seedlings for resistance to $K$. clavus.

Kretzschmaria clavus (isolate Ma-P12) was grown in a wheat-oat medium (125 ml whole wheat, $125 \mathrm{ml}$ whole oat and $100 \mathrm{ml}$ distilled water) for 1 month at $24 \mathrm{C}$. Stems of macadamia seedlings (12 to 18 months old) were scraped gently to remove the epidermis from bark tissues at $10-20 \mathrm{~mm}$ above the ground. About $30 \mathrm{ml}$ of wheat-oat culture on a thin bed of moist sphagunm moss was placed on the scraped portion of the stem, wrapped with a sheet of clear plastic and secured on both ends. Macadamia seedlings similarly inoculated with wheat-oat medium were used as controls. Three replicates were used for each treatment. Young leaves of inoculated seedlings showed water soaking and turned brown within three weeks and died within three months. Infected stems showed black lines and $K$. clavus was reisolated from the diseased tissues. All three control seedlings remained healthy. Similar results were obtained in two subsequent experiments.

The method was used to screen macadamia seedlings for resistance to $K$. clavus. For

\footnotetext{
* Journal Series No. 2979 of the Hawaii Institute of Tropical Agriculture and Human Resources.

** Department of Plant Pathology, University of Hawaii, Beaumont Agricultural Research Center, Hilo, Hawaii 96720, USA.

1) Ko, W. H., Kunimoto, R. K. and Maedo, I. (1977). Phytopathology $67: 18-21.2)$ Ko, W. H., Ho, W. C. and Kunimoto. R. K. (1982). Phytopathology 72 : 1357-1358.
} 
$M$. integrifolia, 18 of 20 inoculated seedlings died within three months. For Macadamia ternifolia F. Muell., 3 of 5 inoculated seedlings died within the same time. All surviving seedlings were planted in the field for further study.

This method is fast and reliable, and should be suitable for use in large-scale screening programs.

We thank Professor Emeritus G. T. Shigeura for supplying seedlings of M. ternifolia.

\section{和 文 摘 要}

Wen-hsiung Ko and Richard K. Kunimoto: Macadamia 実生を用いた Kretzschmaria clavus 抵抗性 の簡易選抜法

マカダミア実生（12〜18カ月苗）の茎の地上部 10２0 cm の部分の表皮を剝ぎ，そこにコムギ・エンバク培 地で24C, 30 日間培養した $K$. clavus を接種すると 3 週間以内に発病し，3カ月以内に枯死した。本法によ り，K. clavus に対するマカダミア実生の抵抗性選拔を検討した結果, Macadamia integrifolia では20本中18 本が, M. ternifolia では 5 本中 3 本がそれぞ枯死した。本法は迅速かつ正確であり，大規模な抵抗性選抜 育種において有効であると考える。 